\title{
Peripheral Target Choice by Homologous Neurons During Embryogenesis of the Medicinal Leech. I. Segment-Specific Preferences of Retzius Cells
}

\author{
Curtis M. Loer ${ }^{\mathrm{a}}$ and William B. Kristan, Jr. \\ Department of Biology, University of California, San Diego, La Jolla, California 92093
}

\begin{abstract}
A pair of large serotonergic neurons, the Retzius $(R z)$ cells, is found in each segment of the leech nervous system. Most Rz cells innervate the body wall of their own segment as well as adjacent anterior and posterior segments. $\mathrm{Rz}$ cells in segments 5 and $6[R z(5,6)]$ instead innervate the reproductive tissue found only in those segments. Rz cells from adjacent segments $[R z(4,7)]$ provide the sertonergic innervation of the body wall of segments 5 and 6 . During embryogenesis, the body wall and the reproductive tissue are apparently available to both $R z(5,6)$ and $R z(4,7)$, yet these neurons choose different targets. We asked how $\operatorname{Rz}(5,6)$ and $R z(4,7)$ choose their respective peripheral targets in the reproductive segments by ablating either the reproductive tissue or specific $\mathbf{R z}$ cells. Ablation of the reproductive tissue caused $\mathrm{Az}(5,6)$ to innervate body wall, although not as proficiently as did standard $R z$ cells, suggesting a preference of $\operatorname{Rz}(5,6)$ for reproductive tissue. Ablation of those $R z$ cells that would normally innervate the body wall of segments 5 and 6 did not cause $R z(5,6)$ to innervate body wall, ruling out competition for this target. When $\mathrm{Rz}(5,6)$ were ablated, $R z(4,7)$ innervated the body wall of segments 5 and 6 normally and did not innervate reproductive tissue. Thus, competition did not act in the choice of target by $R z(4,7)$ either. These results suggest that during normal development, $R z(5,6)$ and $R z(4,7)$ choose their targets independently of one another rather than competing for the available targets and that these cells have segment-specific target preferences.
\end{abstract}

Through the course of its development, a neuron must make a number of decisions that may subsequently alter the choices available to it. The cell extends neurites whose growth cones select central and peripheral pathways along neuronal and nonneuronal substrates (Raper et al., 1983; Tosney and Landmesser, 1985; Caudy and Bentley, 1986; Myers et al., 1986; Jellies and

\footnotetext{
Received Apr. 12, 1988; revised July 15, 1988; accepted July 18, 1988.

We wish to thank John Jellies for invaluable advice and cooperation, Shirley Reynolds and Sheri Furgal for excellent technical assistance, and Carey Booth and Susan Sacks for advice and help with statistical analyses. We also wish to thank John Jellies, Kathy French, and David Bentley for helpful comments on the manuscript. This work was supported by NIH predoctoral Traineeship GM07313 to C.M.L. and NIH Research Grant NS20746 and a March of Dimes Research Grant to W.B.K.

Correspondence should be addressed to William B. Kristan, Department of Biology, B-022, University of California, San Diego, La Jolla, CA 92093.

a Present address: Department of Biochemistry and Biophysics, Box 0554, University of California, San Francisco, CA 94143.

Copyright (C) 1989 Society for Neuroscience $0270-6474 / 89 / 020513-15 \$ 02.00 / 0$
}

Kristan, 1988). The growth cone must also decide when to stop growing and on which cells to synapse. Once chosen, a target may profoundly influence the neuron's survival (Pilar et al., 1980; Lamb, 1981) and subsequent development of morphology, connectivity, and biochemistry (Landis and Keefe, 1983; Doupe et al., 1985; Fujii and Berg, 1987; Loer et al., 1987; Schotzinger and Landis, 1987; Smith and Frank, 1987; Voyvodic, 1987). Thus, the choice of target by a neuron can be pivotal in the sequence of events leading to appropriate function. In the present work, we examined how target choices are made by segmentally homologous identified neurons.

Peripheral processes of most Retzius (Rz) cells extensively innervate the ipsilateral body wall in their own segments (their primary innervation) and, somewhat less extensively, in adjacent anterior and posterior segments (their secondary innervation) (Fig. 1, $A, B$ ). In striking contrast, $\mathrm{Rz}$ cells in ganglia 5 and $6[\mathrm{Rz}(5,6)]$ innervate only the reproductive tissue (Fig. 1, $C, D): \operatorname{Rz}(5)$ innervates the male reproductive tissue in segment 5 , and $\mathrm{Rz}(6)$ innervates both the male reproductive tissue in segment 5 and the female reproductive tissue in segment 6 . During embryogenesis, $\mathrm{Rz}(5,6)$ transiently extend processes laterally into the body wall but later retract these processes and commit their entire peripheral arbor to the medially located reproductive tissue (Jellies et al., 1987). $\mathrm{Rz}(5,6)$ also retract processes in the interganglionic connectives and thus do not establish secondary innervation fields (Glover and Mason, 1986). During the normal course of embryogenesis, the secondary fields of $\mathrm{Rz}$ cells from adjacent segments (4 and 7) provide the innervation of the body wall in the reproductive segments ( 5 and 6) but contribute little innervation to the reproductive tissue.

Contact with the segment-specific target, reproductive tissue, appears to cause $\mathrm{Rz}(5,6)$ to lose both their primary body wall innervation and connective axons supporting a secondary innervation field (Loer et al., 1987). In this paper, we address how $\mathrm{Rz}(5,6)$ and $\mathrm{Rz}(4,7)$ select their respective peripheral targets in the reproductive segments during embryogenesis. The results of experimental manipulations suggest that $\mathrm{Rz}(5,6)$ have a strong preference for reproductive tissue rather than body wall, innervating the body wall only in the absence of their normal target. Although $\mathrm{Rz}(5,6)$ can express characteristics similar to those of standard Rz cells, they may be limited in the degree to which they can become like their segmental homologs. Furthermore, $\mathrm{Rz}(4,7)$ do not innervate reproductive tissue, even in the absence of possible competition from $\mathrm{Rz}(5,6)$. These results suggest that during normal development, $\mathrm{Rz}(5,6)$ and $\mathrm{Rz}(4,7)$ act independently of one another and do not compete for the available targets. 
Figure 1. Segmental differences in peripheral targets of $\mathrm{Rz}$ cells: camera lucida drawings of HRP-filled cells. $A$, Standard Rz cell in ganglion 9 (G9) in a 16-d-old embryo. Three hemisegments of the body wall are shown. Solid line at the right is the lateral edge of the germinal plate. $B$, Outline of cell in $A$ showing processes in the major peripheral nerves. Regions of the body wall of each hemisegment are provided innervation by 1 of 3 peripheral nerves (Ort et al., 1974): The "anterior" $(A)$ nerve innervates anterior ventral and lateral territory, the "dorsal-posterior" $(D P)$ nerve innervates dorsal body wall, and the "posterior-posterior" $(P P)$ nerve innervates posterior ventral and lateral territory. Standard $\mathrm{Rz}$ cells extend processes out each of these nerves and every available nerve branch to fill the entire body wall with serotonergic processes. Rz cell innervation in its segment of origin constitutes its primary $\left(1^{\circ}\right)$ field; innervation of adjacent anterior and posterior segments constitutes secondary $\left(2^{\circ}\right)$ fields. $C, \mathrm{Rz}(5)$ innervating male reproductive tissue in a 17-d-old embryo. $D, \mathrm{Rz}(6)$ innervating male and female reproductive tissue in a 17-d-old embryo. In these preparations, a cut was made along the ventral midline to allow access to the ganglion for HRP injection. Dashed lines outline the ganglia and connectives as well as edges of the ventral midline cut and pinholes (right side of $A$ ). Dotted outlines indicate reproductive tissue. Midline reproductive tissue seen in $C$ and $D$ lies ventral to the nerve cord. Anterior is up in this and all subsequent figures.
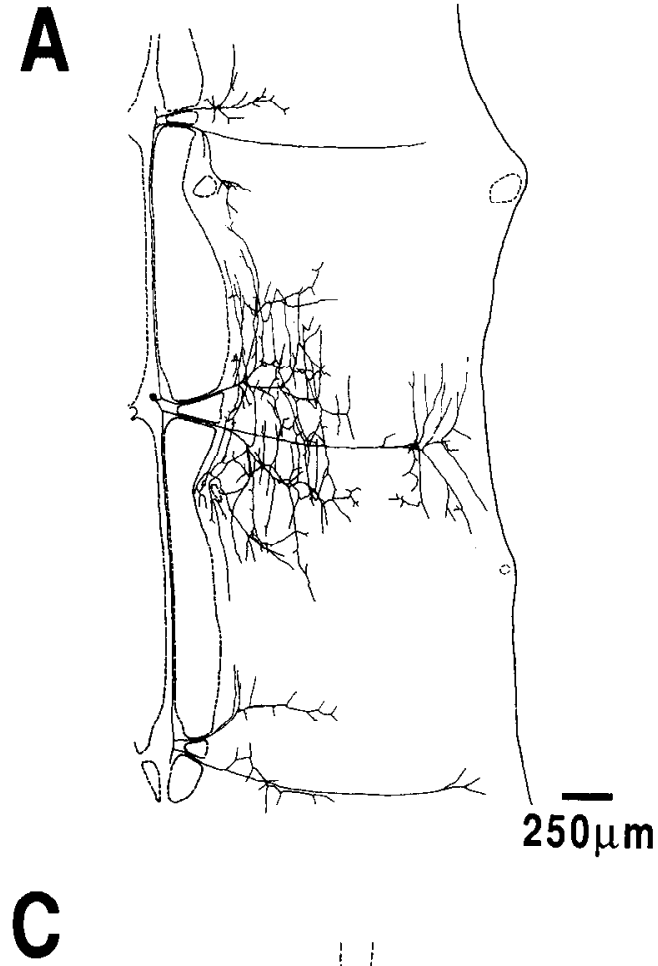

B

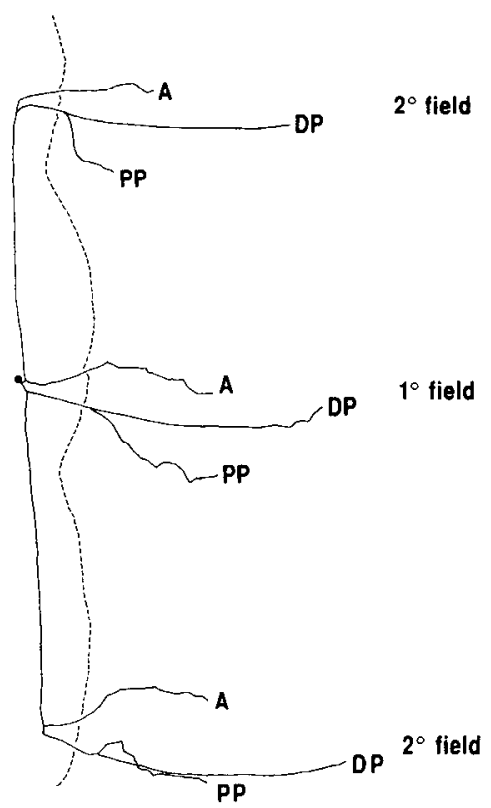

C

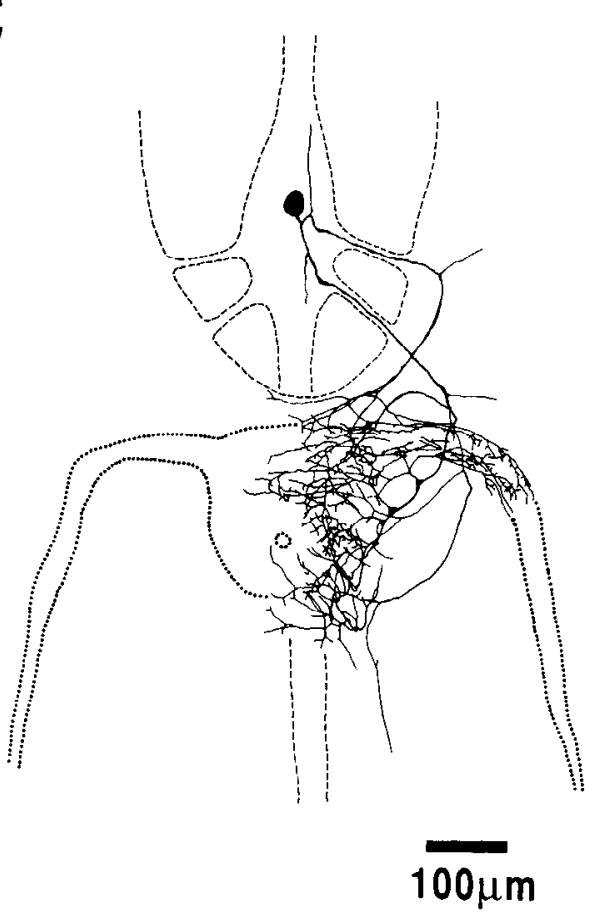

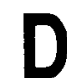

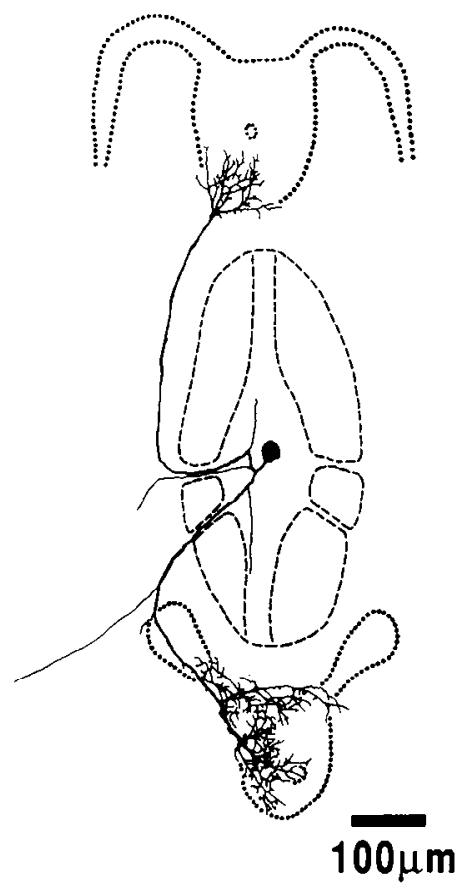

\section{Materials and Methods}

Animals. Embryos of Hirudo medicinalis were obtained from a laboratory breeding colony (Jellies et al., 1987; Loer, 1988) and staged in days of development from the time of cocoon deposition at $22-23^{\circ} \mathrm{C}$ (Fernandez and Stent, 1982).

Segments and their associated ganglia were numbered within the midbody as previously described (Kristan et al., 1974). The first 4 segmental ganglia that fuse during embryogenesis to form the subesophageal ganglion are not counted in this scheme.

Ablation procedures. Reproductive tissue ablations and sham operations were carried out as previously described (Loer et al., 1987). Briefly, late 9- to early 10-d-old embryos were anesthetized in cold $8 \%$ ethanol in leech saline. Reproductive tissue primordia were aspirated with a hand-held micropipette. Sham operations consisted of the removal of a comparable amount of tissue just anterior to the reproductive primordia.

$\mathrm{Rz}$ cells were ablated by 2 different techniques: mechanically with a microelectrode and by "photoablation" with Lucifer yellow (Miller and Selverston, 1979; Jellies and Kristan, 1988). Embryos were first anesthetized in cold $8 \%$ ethanol in leech saline and placed ventral side up in rectangular chambers cut into Sylgard-filled plastic petri plates. The embryo was usually restrained further with one or 2 thin plastic strips across the germinal plate pinned down on either side, effectively strapping the embryo in place.

Mechanical ablations were performed by passing a hand-held microelectrode 10-15 times through the ganglion in the central region where the $R_{z}$ cells are located. The embryo was lighted from the side and viewed through a dissecting microscope.

Embryos were prepared for photoablation by making a slit over the 
appropriate ganglia with a fine tungsten needle. The preparation was subsequently viewed through the compound microscope with bright transmitted light. A Rz cell located by its position in the ganglion was impaled and sufficient Lucifer yellow injected into the cell to confirm its identity when viewed briefly with epifuorescence. In each identified $\mathrm{Rz}$ cell, continuous hyperpolarizing current was applied for 1-2 min until the cell was bright yellow. For each ganglion, cells were impaled and identified until both $\mathrm{Rz}$ cells were filled. In most preparations, 12 cells were filled in addition to $\mathrm{Rz}$. The ganglion was then illuminated with intense blue light for about $5 \mathrm{~min}$, at the end of which the dyefilled cells had begun to break up and their fluorescence had faded considerably. Both ablation methods were considered successful when the 5-HT-immunoreactive somata of the Rz cells were absent from the ganglion following anti-5-HT immunohistochemistry. Other 5-HT cells usually appeared to be undisturbed by the ablation procedures. Segments missing other 5-HT-immunoreactive somata or with grossly abnormal ganglia or reproductive tissue were excluded from analysis.

The photoablation technique was highly specific and reliable for killing $\mathrm{Rz}$ cells, but it required cuts in the body wall overlying the ganglia, as well as extended viewing time with bright transmitted and epifluorescent light while the embryo was anesthetized. Consequently, the technique was more likely to damage or kill embryos than were mechanical ablations. Although the mechanical technique was less reliable and less specific, it was very rapid, and a larger fraction of embryos survived. The fact that both techniques yielded similar results suggests that no systematic but unidentified damage produced the observed results.

Animals from a single cocoon (late day 9 to early day 10) containing 15-25 embryos were used for each experiment. At the beginning of each experiment, 2 embryos from the cocoon were dissected, fixed, and subsequently stained with 5-HT anti-serum and an HRP-conjugated $2^{\circ}$ antibody (Jellies et al., 1987) to assess the developmental age of the $\mathrm{Rz}$ cells at the time of the operation. Following all manipulations, experimental, sham-operated, and unoperated control siblings were placed individually in sterile $35 \times 10 \mathrm{~mm}$ plastic petri dishes in $5 \mathrm{ml}$ of sterile spring water (Jellies et al., 1987) and allowed to develop further. They were dissected, fixed, and stained for the presence of 5-HT at later stages.

Staining of $R z$ cell processes. $\mathrm{Rz}$ cells processes can be stained completely with 5-HT antiserum from shortly after they first begin to extend neurites throughout embryogenesis (Glover and Mason, 1986; Jellies et al., 1987). Staining with serotonin antiserum was performed as previously described (Jellies et al., 1987). Briefly, following dissection and fixation overnight in either $4 \%$ paraformaldehyde or $1.5 \%$ picric acid/

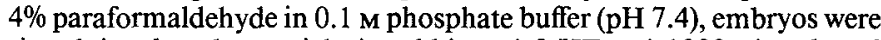
rinsed, incubated overnight in rabbit anti-5-HT at 1:1000, rinsed, and then incubated overnight with the secondary antibody, HRP-conjugated goat anti-rabbit IgG, also at 1:1000. Following another rinse, they were reacted with $0.05 \% \mathrm{DAB}$ with $\mathrm{H}_{2} \mathrm{O}_{2}$, dehydrated, cleared in xylene, and mounted in Permount on glass slides.

$\mathrm{Rz}$ cell processes were also stained by filling individual cells with HRP with intracellular microelectrodes. The procedure was performed as previously described (Jellies et al., 1987), except for the following: Injections were carried out with embryos in $8 \%$ ethanol in a solution of saline supplemented with $70 \%$ L-15 medium; and, following injections, embryos were incubated in $100 \% \mathrm{~L}-15$ medium for $5-7 \mathrm{hr}$ at room temperature $\left(22-23^{\circ} \mathrm{C}\right)$ or $12-15 \mathrm{hr}$ at $15^{\circ} \mathrm{C}$. These longer times allowed for filling of peripheral processes at the expense of intraganglionic processes, which were poorly preserved. In some cases, to facilitate filling of distant secondary innervation fields, nerve roots and connectives containing axons extending away from the site of interest were crushed with forceps following injection. Embryos were fixed with $2 \%$ paraformaldehyde $/ 2 \%$ glutaraldehyde in phosphate buffer for $30 \mathrm{~min}$ to $1 \mathrm{hr}$ at $4^{\circ} \mathrm{C}$, rinsed, permeabilized with $0.5 \%$ saponin, and reacted with diaminobenzidine and $\mathrm{H}_{2} \mathrm{O}_{2}$, dehydrated, cleared, and mounted as previously described (Jellies et al., 1987).

Measurements of $\mathrm{Kz}$ cell peripheral processes. The extent of lateral growth of $\mathrm{Rz}$ cell processes was measured in 3 major peripheral nerves (A, PP, and DP) in stained preparations (see Fig. 1). Rz cells are the only 5-HT-containing cells known to extend into the periphery. The length of a process was normalized to the distance between the edge of the ganglion and the edge of the germinal plate (Jellies et al., 1987). Normalizing the value was necessary because embryos are of different sizes and because the body wall is stretched different amounts during dissection in different embryos and different hemisegments. The lengths of processes on both sides of each segment were measured, except in a few cases in which one hemisegment was damaged during dissection. These 2 values were treated as independent measurements based on calculations of independence of comparable measurements made for experiments described in the following paper (Loer and Kristan, 1989).

Most statistics were computed on an Apple Macintosh Plus computer using StatView $512+$ (BrainPower, Inc.). Comparisons with 3 or more groups were made by 1-factor ANOVA; planned pairwise comparisons were made with additional $F$ tests (Sokal and Rohlf, 1981). Comparisons with only 2 groups were made with Student's $t$ test.

\section{Results}

Development of normal serotonergic innervation of the body wall of segments 5 and 6

Although $\mathrm{Rz}(5,6)$ do not innervate the body wall, segments 5 and 6 in late embryos and adults appeared to be as extensively innervated by 5 -HT-containing fibers as were those of standard segments (Fig. 2). Previous work has suggested that this innervation is provided by the secondary fields of $\mathrm{Rz}(4)$ and $\mathrm{Rz}(7)$ (Jellies et al., 1987). Individual $\mathrm{Rz}(4)$ and $\mathrm{Rz}$ (7) filled with HRP at $16 \mathrm{~d}$ (Fig. 3, $A, B$ ) confirmed this interpretation; their secondary arbors were essentially coextensive with 5 -HT-stained processes in the body wall of segments 5 and 6 at that age (Fig. 4). $\mathrm{Rz}(4)$ and $\mathrm{Rz}(7)$ provided little innervation of the reproductive tissue, although they extended not only out the 3 major segmental nerves (A, PP, and DP) but also grew along the same segment-specific "sex nerves" to the reproductive tissue as did $\mathrm{Rz}(5,6)$. The few branches $\mathrm{Rz}(4)$ and (7) sent to the reproductive tissue were thin and sparsely branched, unlike those typical of $\mathrm{Rz}(5,6)$. Similar comparisons of processes of individual $\mathrm{Rz}$ cells with 5-HT-containing processes in 12-18 d embryos led us to conclude that the 5-HT staining in the body wall in nonreproductive segments during development represents the outgrowth of primary processes from $\mathrm{Rz}$ cells, whereas in segments 5 and 6 , it represents the outgrowth of secondary processes from $\mathrm{Rz}$ cells in adjacent segments.

Because the growth of $\mathrm{Rz}$ processes into secondary fields lags behind that of primary fields, it was not surprising that the 5-HT innervation of segments 5 and 6 was found to lag behind that of nearby standard segments. This difference was especially apparent on days 12 and 14, when 5-HT processes in segments 4 and 7 extended much further laterally in all major segmental nerves than did those in segments 5 and 6 (Fig. 5). During the same period, $\mathrm{Rz}(5,6)$ processes in association with the reproductive tissue increased in density and complexity, while those in the body wall were retracting (see also Jellies et al., 1987). R7. (4) and (7) provided only a few branches to the reproductive tissue; their branches grew instead into the uninnervated body wall.

These observations suggested that $\mathrm{Rz}(4,7)$ and $\mathrm{Rz}(5,6)$ might be competing for targets. Perhaps $\mathrm{Rz}(5,6)$, being first to innervate segments 5 and 6 , innervated the more desirable target (i.e., the reproductive tissue), forcing the late-arriving $\mathrm{Rz}(4,7)$ processes to innervate the remaining target (the body wall). We tested this hypothesis by performing 3 types of manipulations: ablation of reproductive tissue, ablation of $\mathrm{Rz}$ cells anterior to segment 5 and posterior to segment 6 , and ablation of $\mathrm{Rz}(5,6)$.

\section{Effect of ablating reproductive tissue on serotonergic innervation of body wall in segments 5 and 6}

Following ablation of reproductive tissue, an extensive serotonergic arbor was found in segments 5 and 6 , especially in the ventral body wall near the ganglia (Fig. 6). Although the extent of the arbor appeared roughly normal for these segments at this 
Figure 2. Rz cell processes in the body wall and reproductive tissue of a 22-dold embryo: camera lucida drawing of preparation stained with 5 -HT antiserum and HRP-conjugated $2^{\circ}$ antibody (anti-5-HT). In this and all subsequent camera lucida drawings of anti-5-HT preparations, 5-HT-containing fibers and somata in the CNS are not drawn except for the outlines of the $\mathrm{Rz}$ cell bodies. (The other 5-HTcontaining neurons do not send processes to the periphery.) Shown here is the left side of segments 5-7. The dashed lines outline the CNS, consisting of the ganglia and connectives. Dots outline the reproductive tissue, the innervation of which is shown only for the left side. The dotted line leading posteriorly from the male reproductive tissue represents the vas deferens, which continues to segment 15 . The solid line at left indicates the dorsal midline; the lateral edges of the germinal plate met and fused to form the dorsal midline at $20 \mathrm{~d}$ of development. G5-G7 indicate ganglia 5-7.

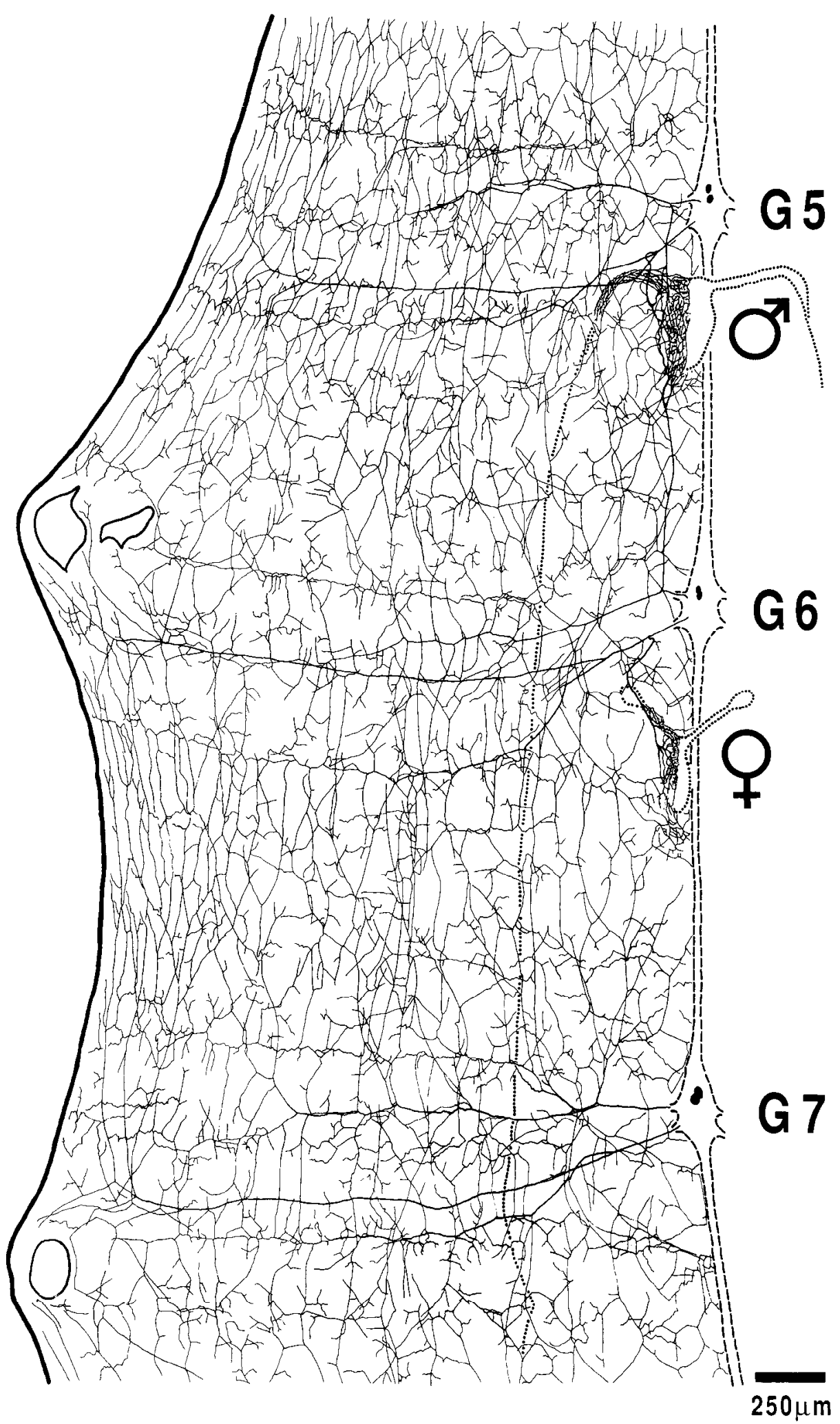

time, many of the branches were heavicr than those usually found in standard segments and more closely resembled the branches normally associated with the reproductive tissue. Frequently, a dense cluster of branches was associated with the terminal region of the nephridium, the nephridial bladder and pore (29/34 hemisegments, 17 embryos). This heavy innervation of the nephridiopore region was rare in unoperated seg- ments 5 and $6(1 / 57$ hemisegments, 16 embryos $)$ and standard segments (5/490 hemisegments, 30 embryos). The nephridiopore tissue may share some properties with genital pore tissue since in a few embryos with incomplete ablations some remaining reproductive tissue was associated with a nephridiopore. The nephridial bladder has been reported to be a normal target of serotonergic processes in the adult (Leake et al., 1985). 

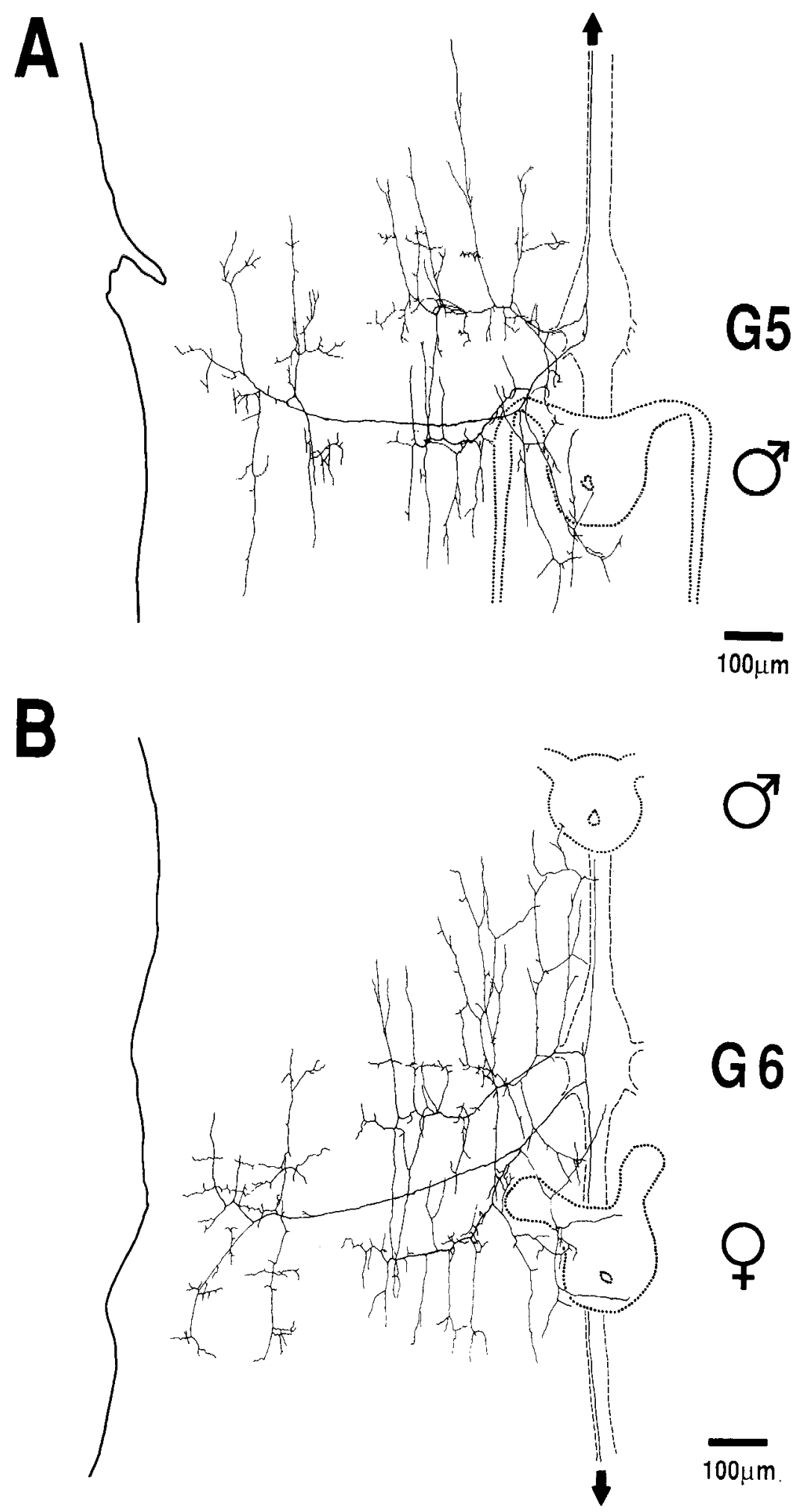

Figure 3. Innervation of body wall in reproductive segments by secondary fields of $\mathrm{Rz}$ (4) and $\mathrm{Rz}$ (7): camera lucida drawings of HRP-filled cells in 16 $\mathrm{d}$ embryos. $A$, Innervation of segment 5 by $\mathrm{Rz}$ (4) secondary field. $B$, Innervation of segment 6 by $R z(7)$ secondary field. Dashed lines outline the CNS. Dots outline reproductive tissue. The solid line at the left indicates the lateral edge of the germinal plate. Arrows indicate the continuation of the process anteriorly to $\mathrm{G} 4(A)$ or posteriorly to $\mathrm{G} 7$ $(B)$.

In embryos from which the reproductive tissue had been ablated, the morphology of individual $\mathrm{Rz}(5,6)$ filled with HRP could account for the 5-HT staining described above, showing extensive branching, especially in the ventral body wall (Fig. 7). These processes were often thicker than those of standard Rz cells and were sometimes associated with the nephridial bladder and pore. Extending previous results (Loer et al., 1987), we found that these cells often projected axons through the interganglionic connectives and adjacent segmental ganglia and into the periphery, where they established secondary fields. Although these $\mathrm{Rz}(5,6)$ processes made a peripheral arbor similar to that of standard $\mathrm{Rz}$ cells, serotonergic innervation of body wall in segments 5 and 6 still appeared to lag behind that of segments 4 and 7 . We confirmed this impression by measuring the furthest 


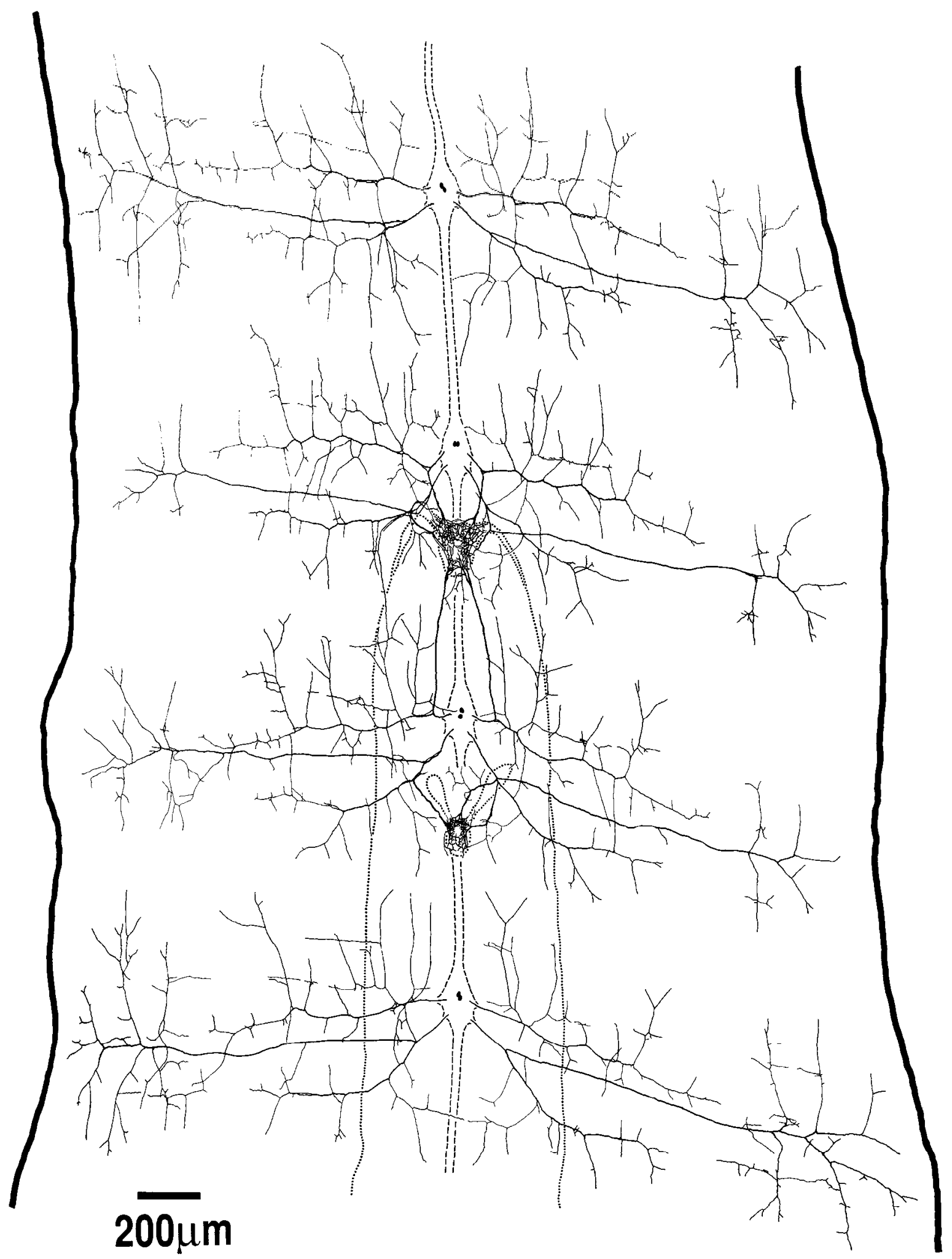

Figure 4. 5-HT innervation of segments 4-7 in a $16 \mathrm{~d}$ embryo: camera lucida drawing of preparation stained with anti-5-HT. Dashed lines outline the CNS. Dots outline reproductive tissue. The dotted line leading posteriorly from the male reproductive tissue represents the vas deferens, which continues to segment 15 . The solid lines on either side indicate the lateral edges of the germinal plate.

lateral growth of 5-HT-containing processes in 3 major nerves (A, PP, and DP); $2 \mathrm{~d}$ after operations, we found no significant differences ( 1 factor ANOVA, $p>0.1$ ) between the extent of growth in experimentals, sham-operated controls, and unop- erated controls in the PP and DP nerves of segments 5 and 6 (Fig. 8). There were, however, significant differences among the 3 groups in the A nerves of both segments 5 and 6 . In both cases, the average length of processes was shorter in experi- 

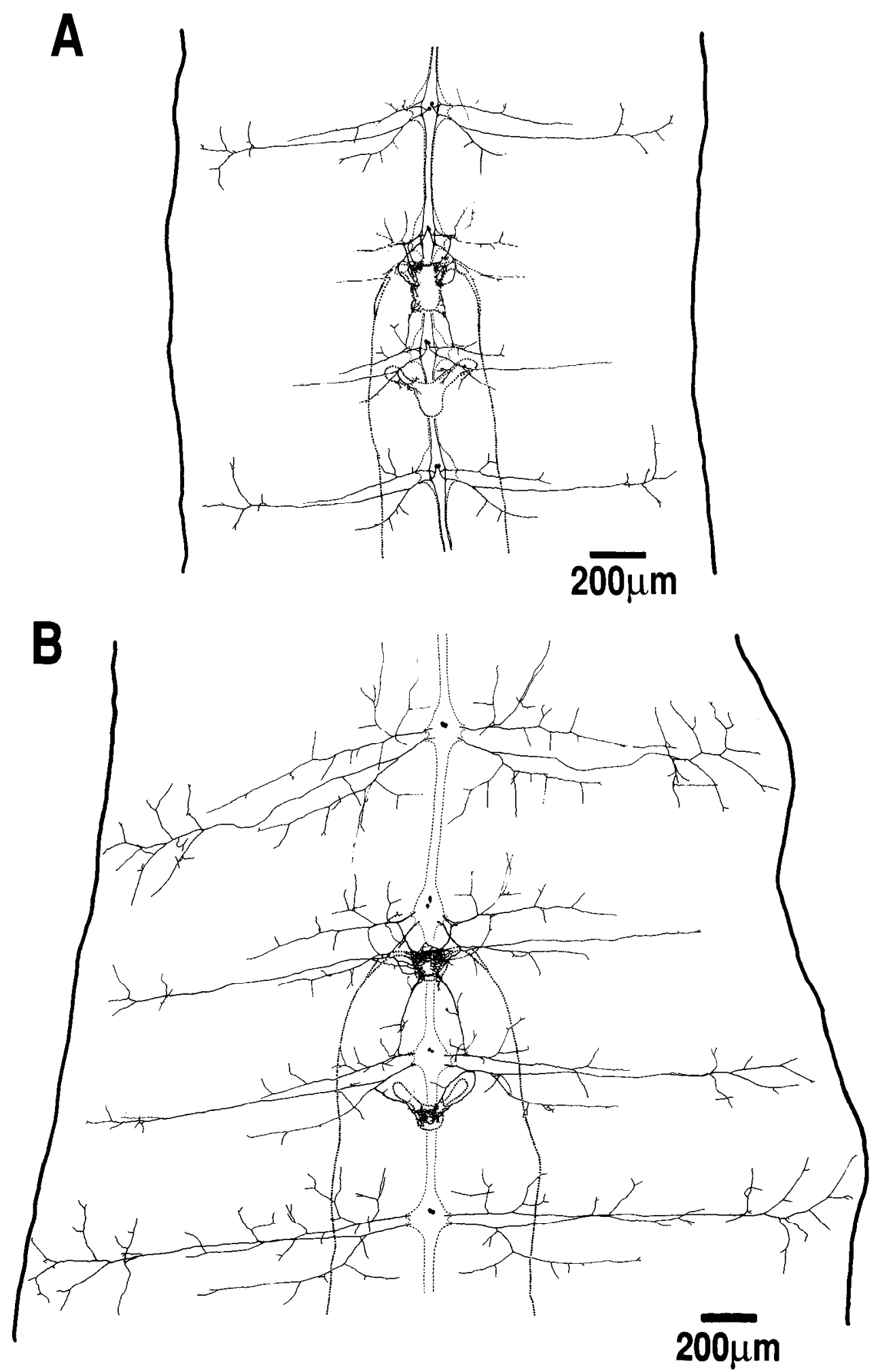

Figure 5. Development of 5-HT innervation of segments 4-7: camera lucida drawings of preparations stained with anti-5-HT. $A$, Twelve day embryo. $B$, Fourteen day embryo. Structures are outlined as in Figure 4.

mentals than controls. These results show that $\mathrm{Rz}(5,6)$ deprived of their normal target innervate the body wall more slowly than do standard $\mathrm{Rz}$ cells.

\section{$R z(5,6)$ innervation of segments 5 and 6 in the absence of other $R z$ processes}

$\mathrm{R}_{L}(5,6)$ initially extend processes laterally into the body wall but retract them during the time when $\mathrm{Rz}$ (4) and (7) grow into segments 5 and 6 (Jellies et al., 1987). We ablated $R z(4,7)$ to determine whether the lateral branches of $R z(5,6)$ would persist if the body wall were not innervated by other 5 -HT processes while their processes were being retracted. $\mathrm{Rz}$ cells from these adjacent segments were ablated late on day 9 , before their processes reached segments 5 and 6 and before $\mathrm{Rz}(5,6)$ were morphologically distinguishable from their segmental homologs. After 4-6 d, we evaluated the serotonergic innervation of segments 


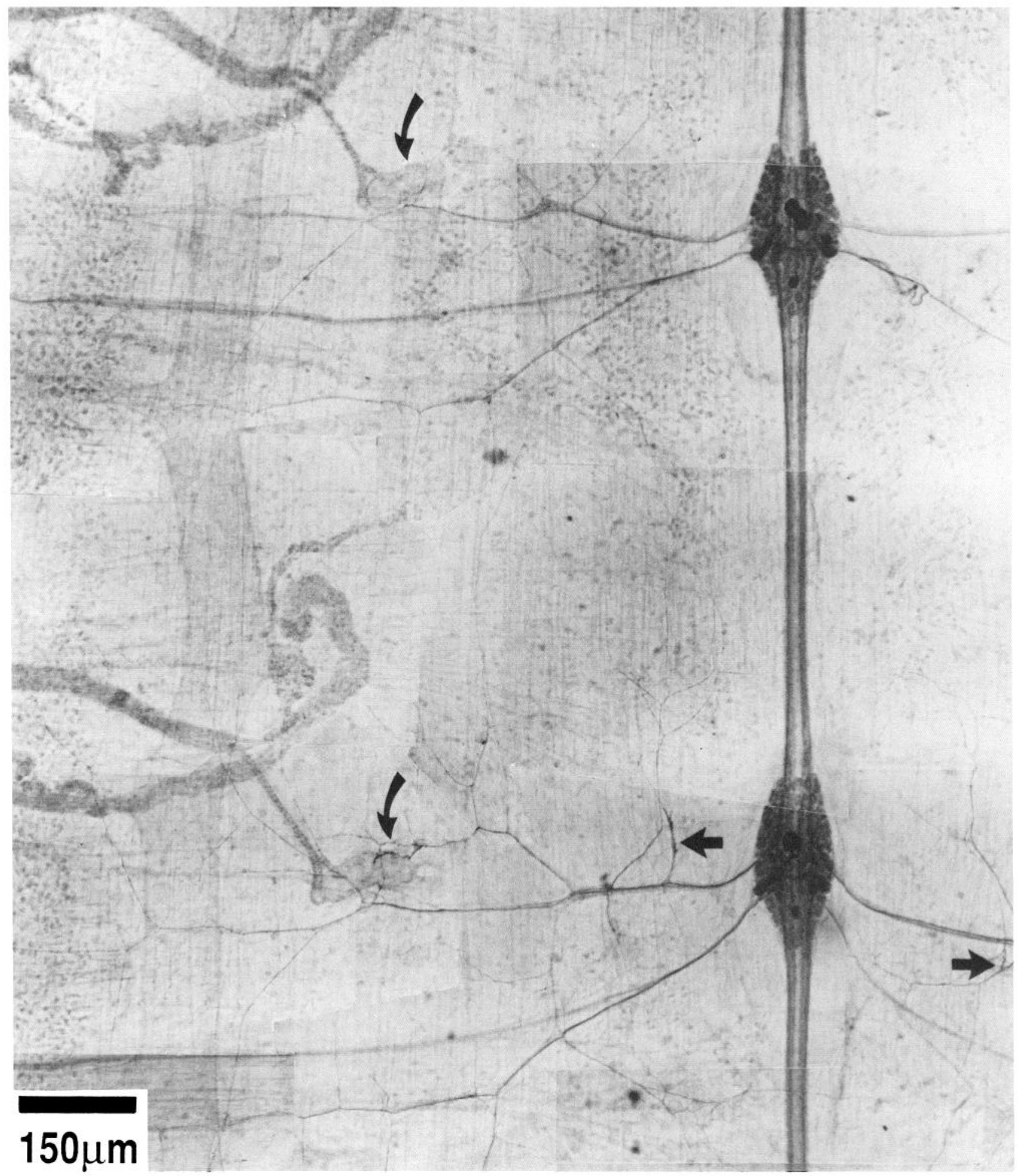

Figure 6. 5-HT innervation of segments 4 and 5 following ablation of reproductive tissue. This is a photomontage of left ventral and lateral body wall of segments 4 and 5 in a preparation stained with anti-5-HT. Curved arrows indicate the nephridial bladder and pore regions. Note the heavy branches on the nephridial bladder in segment 5. Straight heavy arrows in segment 5 indicate 2 thick and heavy branches, perhaps remnants of the sex nerves of the anterior root of ganglion 5; these would normally extend posteriorly toward the male reproductive tissue.

5 and 6. Embryos from which $\mathrm{Rz}(4)$ and (7) had been ablated frequently showed considerable serotonergic innervation in the body wall of segments 5 and 6 . There were, however, also 5-HT-containing processes in segments 4 and 7 in such embryos. The fibers in segments 4 and 7 were probably $2^{\circ}$ fields of $R z$ (3) and (8), suggesting that these Rz cells may also have been responsible for the body wall innervation of segments 5 and 6 by way of $3^{\circ}$ branches. Whether $\mathrm{Rz}(3)$ and (8) have $3^{\circ}$ fields normally or instead expanded their peripheral territories after the ablations is unclear (see Discussion). 


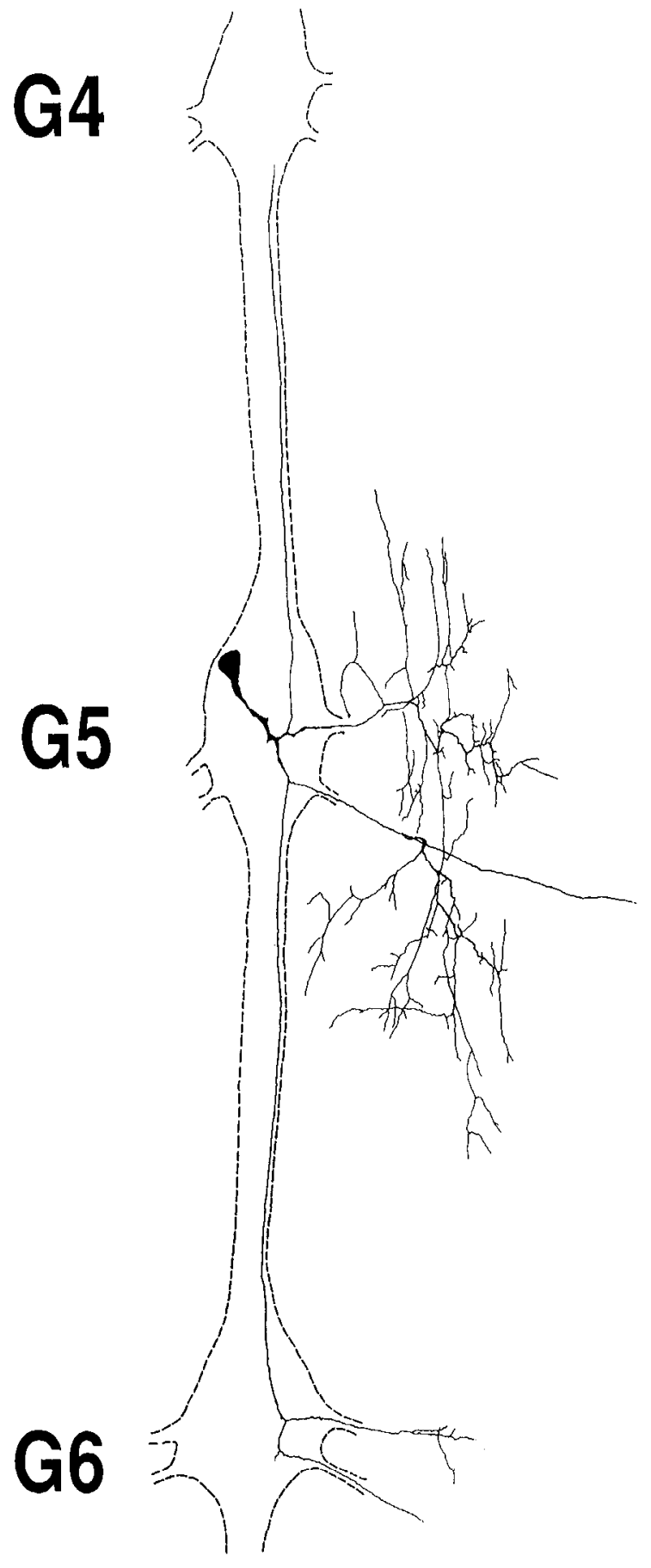

To ensure that segments 5 and 6 were free of all $\mathrm{Rz}$ innervation from adjacent segments, we made more extensive ablations: $\mathrm{Rz}$ $(3,4,7,8)$, or $\mathrm{Rz}(2-4,7-9)$, or $\mathrm{Rz}(4,7)$ followed by severing connectives between $\mathrm{G} 3$ and $\mathrm{G} 4$ and between $\mathrm{G} 7$ and G8. Embryos that lacked serotonergic innervation of the body wall of segments 4 and 7 also lacked such innervation in segments 5 and 6 (Fig. 9A). These results were obtained for segment 5 in 16 of 16 hemisegments ( 8 embryos) and for segment 6 in 17 of 17 hemisegments ( 9 embryos). In such embryos, the 5-HT staining pattern resembled that of normal $\mathrm{Rz}(5,6)$ filled with HRP: The reproductive tissue was heavily innervated, and there were either no processes or only a few fine processes that extended laterally into the body wall. Hence, $\mathrm{Rz}(5,6)$ retracted their pro-

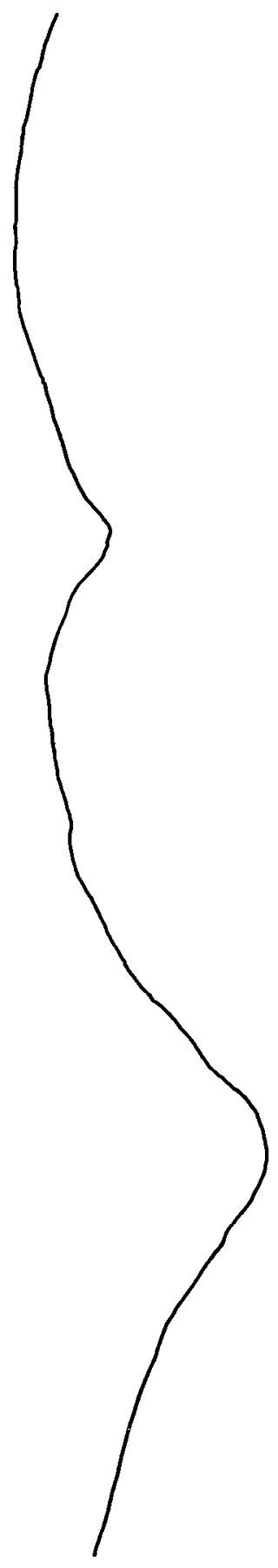

Figure 7. Peripheral branches of an individual $\mathrm{Rz}(5)$ following reproductive tissue ablation: camera lucida drawing of HRP-filled cell in a $15 \mathrm{~d}$ embryo. The cell body was dislodged from its usual central position in the ganglion during dissection subsequent to intracellular HRP injection. Dashed lines outline the ganglia and connectives. The solid line at right marks the lateral edge of the germinal plate. cesses from body wall targets on schedule, even though there was no competition for these targets, while retaining contact with their normal targets. These results suggest that $\mathrm{Rz}(5,6)$ have a very strong preference for reproductive tissue, even in the presence of vast expanses of uninnervated body wall.

$R z$ (4) and (7) innervation of segments 5 and 6 in the absence of $R z(5,6)$

Under normal circumstances, $\mathrm{Rz}(4,7)$ never innervate reproductive tissue heavily, a lack that might arise from a disadvantageous competition with $\mathrm{Rz}(5,6)$ processes, which reach the tissue first. We tested this possibility directly by giving $R z(4,7)$ processes unhindered access to the reproductive tissue; we killed 


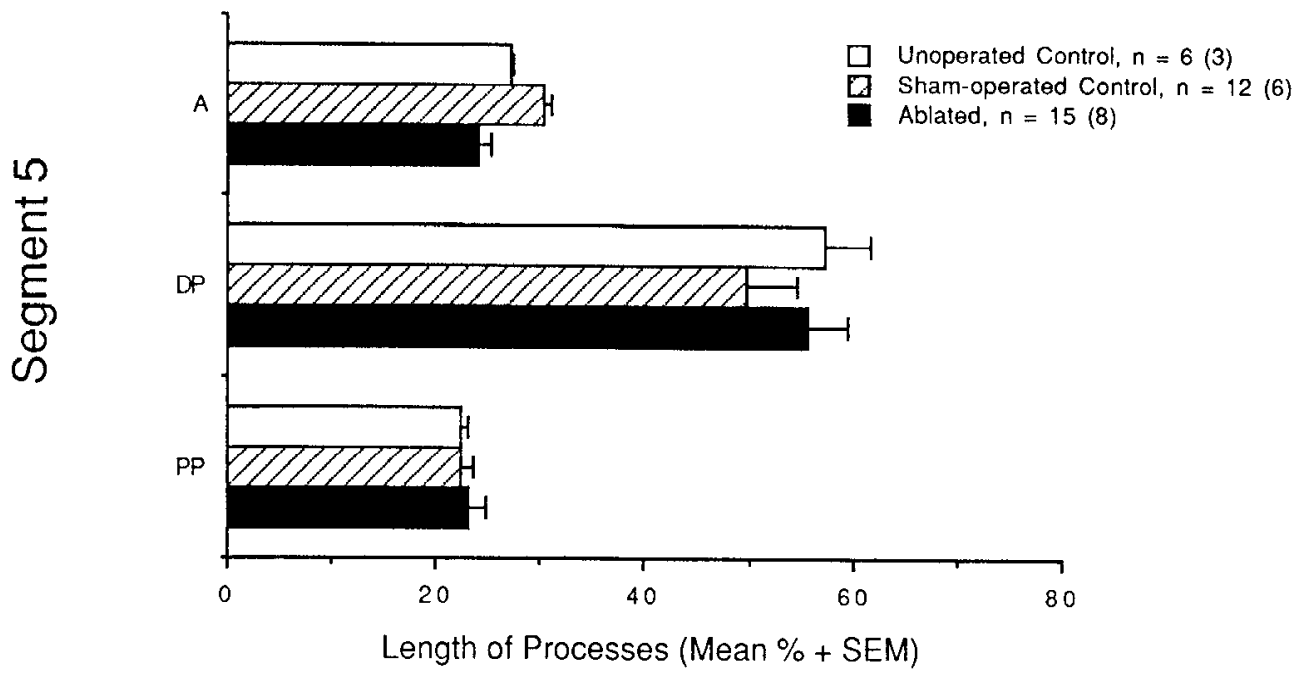

Figure 8. Extent of lateral growth of processes in A, PP, and DP nerves of segments 5 (top) and 6 (bottom) in reproductive tissue ablated, sham-operated, and unoperated control embryos measured in anti-5-HT preparations. The embryos were dissected $2 \mathrm{~d}$ after the manipulation. Mcan ( 1 SEM) length of process is expressed as a percentage of the distance from the ganglion to the edge of the germinal plate (see Materials and Methods). $n$ indicates the number of hemisegments measured; number in parentheses indicates the number of embryos.

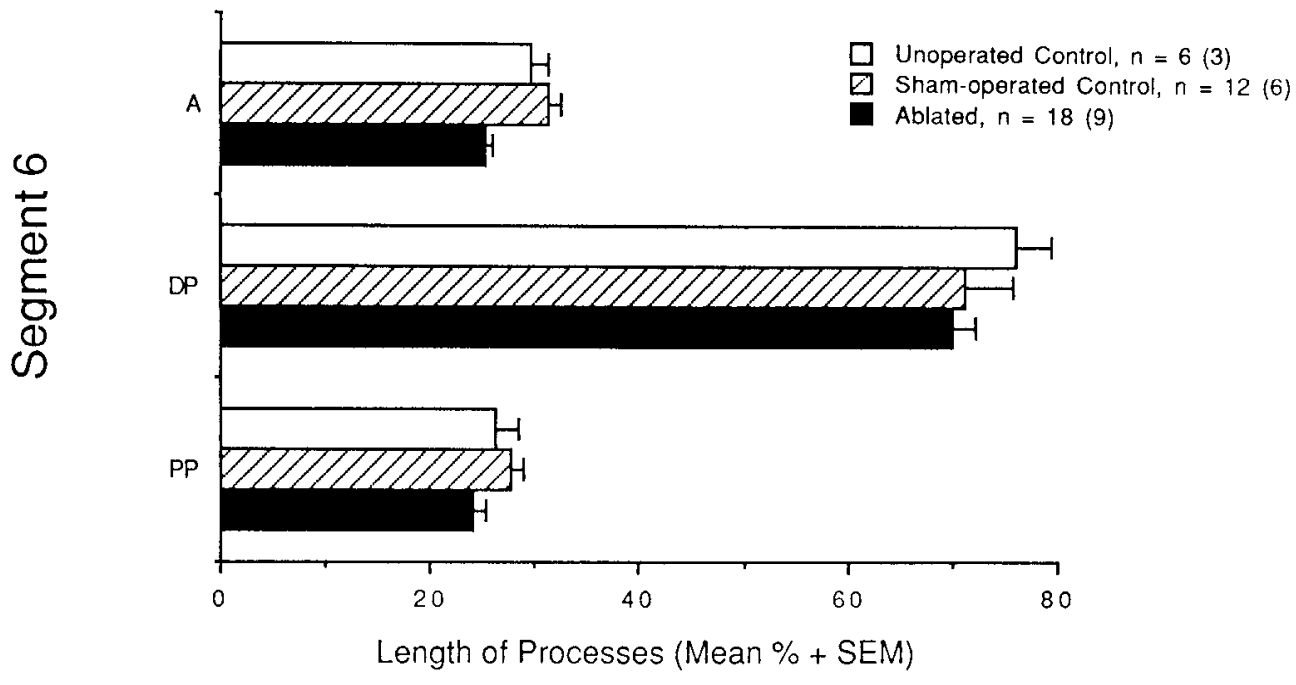

$\mathrm{Rz}(5,6)$ at early stages and determined the extent of reproductive tissue and body wall innervation at later stages. In embryos in which all $4 \mathrm{Rz}(5,6)$ were successfully ablated, the staining pattern revealed with 5-HT antiserum resembled that of $\mathrm{Rz}(4)$ and (7) filled with HRP. Innervation of male (8/8) and female $(10 / 10)$ reproductive tissue was sparse, whereas the innervation of body wall was normal (Figs. 9B, 10). In all embryos in which both $\mathrm{Rz}(6)$ cells were ablated, the female reproductive tissue received little or no serotonergic innervation (17/17). Some 5 -HT processes, presumably originating from $\mathrm{Rz}(4)$ and (7), did reach the male and female reproductive tissue by the pathways normally taken by $\mathrm{Rz}(5,6)$, indicating that scgment-specific sex nerves formed without $\mathrm{Rz}(5,6)$ (see also Jellies and Kristan, 1988). These processes were uniformly simple, typical of those in the body wall and unlike the heavier, more complex processes of $\mathrm{Rz}(5,6)$ in reproductive tissue (Fig. 10).

Embryos in which 1,2 , or $3 \mathrm{Rz}(5,6)$ survived the ablation attempt showed a variety of outcomes. Loss of a single Rz (6) caused a noticeable decrease in innervation of female reproductive tissue, which normally receives branches only from the $2 \mathrm{Rz}(6)$ cells. The serotonergic innervation of male reproductive tissue, which normally receives branches from all $4 \mathrm{Rz}(5,6)$, appeared normal or near normal with 3 cells remaining. Innervation was still quite dense with only $2 \mathrm{Rz}(5,6)$ remaining but was much decreased when only a single $\mathrm{Rz}(5,6)$ remained. It is unclear whether the near-normal appearance of 5-HT innervation of male reproductive tissue with 1 or $2 \mathrm{Rz}(5,6)$ missing represents a compensatory expansion of the processes from the remaining cells or merely reveals the normal overlap of individual $\mathrm{Rz}(5,6)$ with one another; normal $\mathrm{Rz}(5,6)$ filled with HRP did not neatly divide up the available space on the male reproductive tissue but freely overlapped with their contralateral and segmental homologs.

Similarly, the sex nerves that normally served as pathways for missing $\mathrm{Rz}$ cells often still contained heavy processes when 1 or more $\mathrm{Rz}(5,6)$ were missing. It seems likely that these 

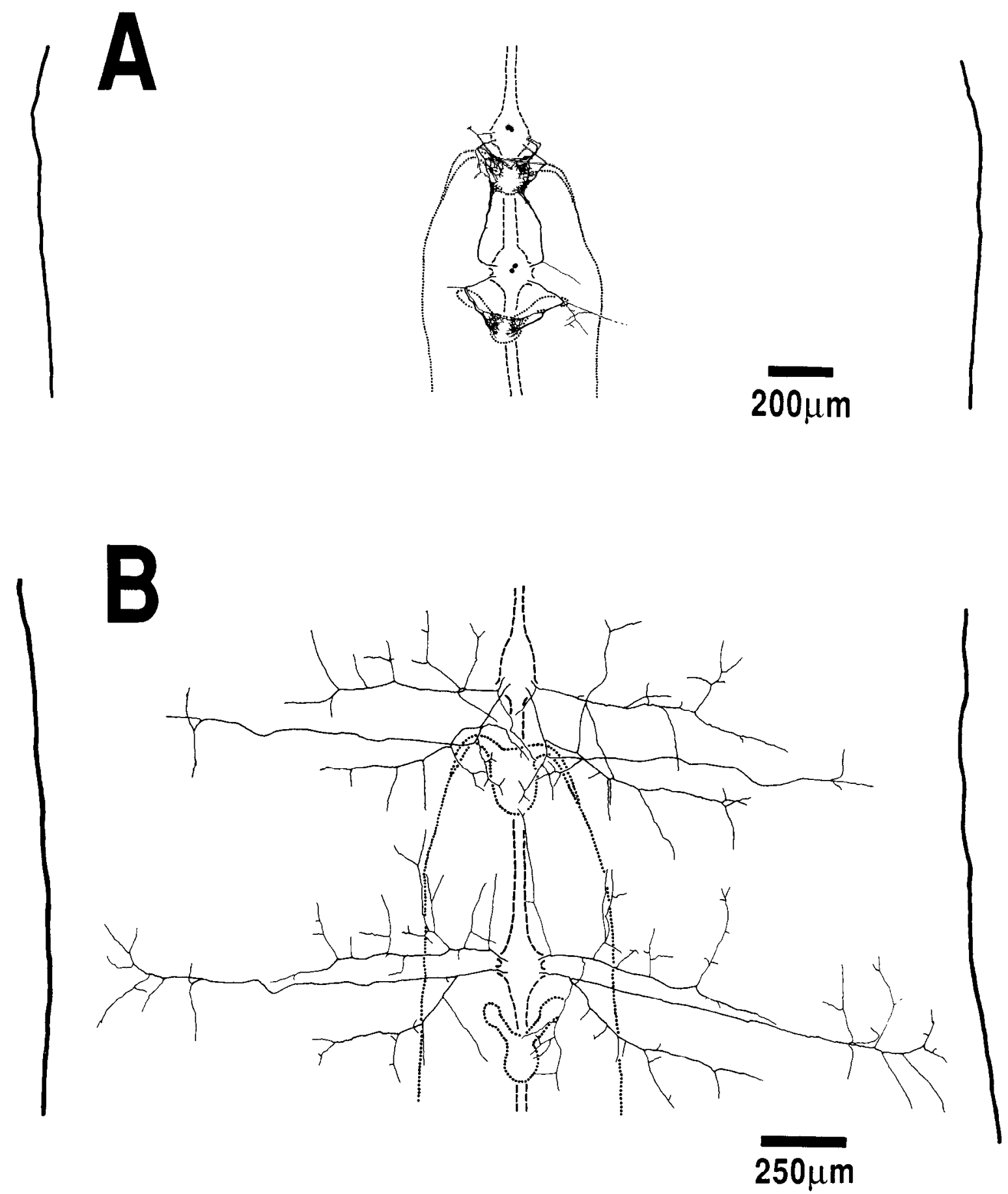

Figure 9. A, Serotonergic innervation of segments 5 and 6 following ablation of Rz cells in adjacent segments: camera lucida drawing of preparation stained with anti-5-HT. The ganglia and nerves of segments 5 and 6 are completely normal in this 14-d-old embryo; serotonergic innervation of the body wall at this age normally looks like that seen in Figures $5 B$ or $9 B$. This preparation also lacked serotonergic innervation in the body wall of segments 4 and 7. B, 5-HT innervation of segments 5 and 6 following $\mathrm{Rz}(5,6)$ ablation: camera lucida drawing of 14-d-old embryo stained with anti-5-HT. Structures are outlined as in Figure 4.

processes belong to the remaining $\mathrm{Rz}(5,6)$, which sometimes grow retrogradely into these pathways. Normal $\mathrm{Rz}(5)$ cells often extend such "wrong way" processes into the sex nerve of the anterior root of ganglion 6 (Fig. $1 B$ ).

When $\mathrm{Rz}(5,6)$ contact reproductive tissue during normal development, they cease growing processes into the body wall. If $\mathrm{Rz}(4,7)$ were interacting with reproductive tissue more than usual in the absence of $\mathrm{Rz}(5,6)$, the growth of their processes into the body wall of segments 5 and 6 might be retarded. We testcd this possibility by measuring the lateral growth of $5-\mathrm{HT}$ processes in 3 peripheral nerves (A, DP, PP) of segments 5 and 6. Serotonergic innervation of the body wall in segments 5 and 6 was unaffected by $\mathrm{Rz}(5,6)$ ablation (Fig. 11). There were no significant differences ( $p>0.05$, Student's $t$ test) between the normalized lengths of 5-HT processes from $\mathrm{Rz}(5,6)$-ablated embryos and unoperated control siblings in the A, PP, and DP 

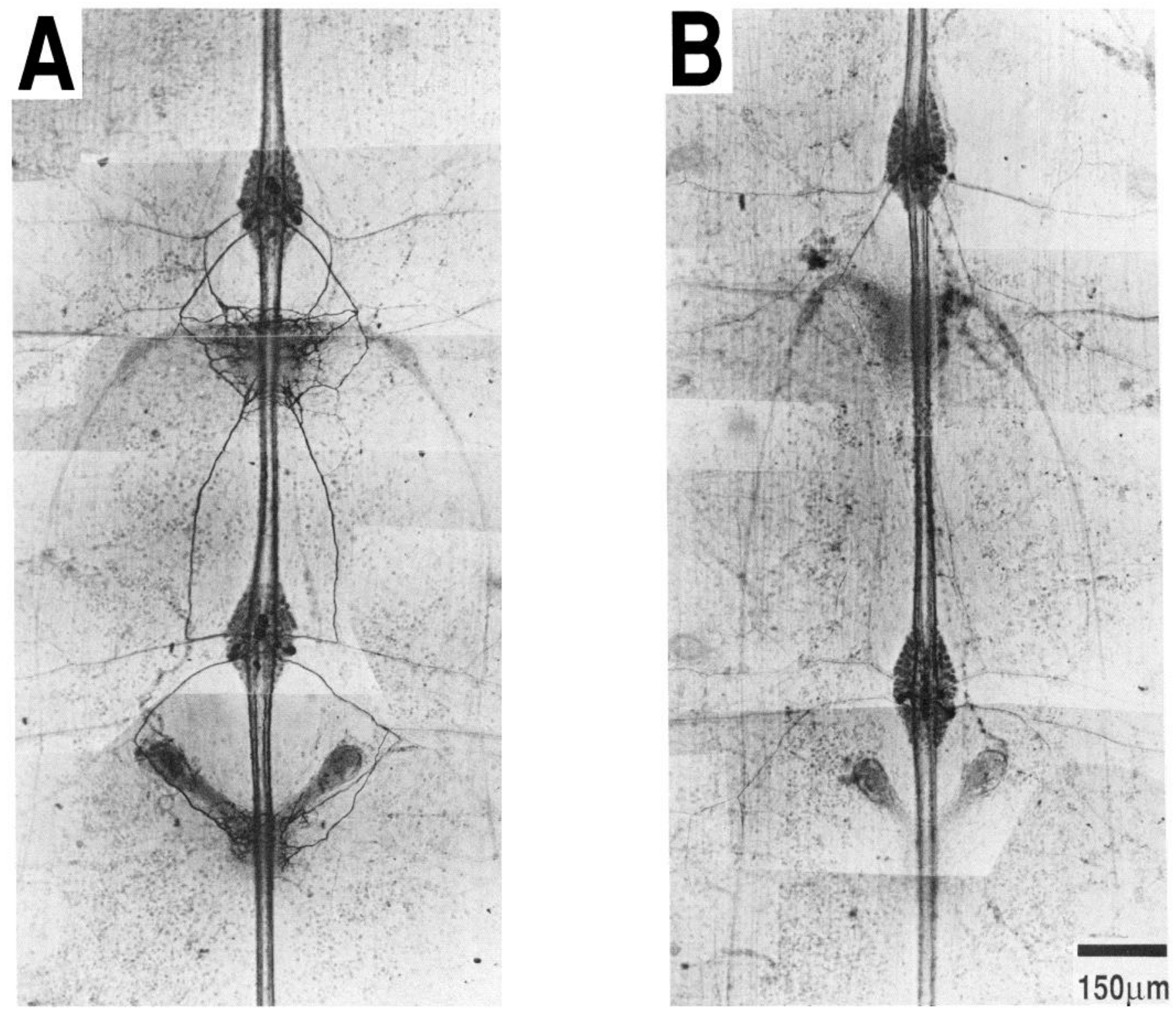

Figure 10. Normal innervation of male and female reproductive tissue $(A)$ and innervation of male and female reproductive tissue following ablation of $\mathrm{Rz}(5,6)(B)$. Photomontages of $14 \mathrm{~d}$ embryos stained with anti-5-HT. $B$ is from the embryo depicted in Figure $9 B ; A$ is from an unoperated sibling.

nerves of either segments 5 or 6 . This shows that $\mathrm{Rz}(4,7)$ innervation of the body wall of segments 5 and 6 proceeded unperturbed by free access to the reproductive tissue.

\section{Discussion}

Target choice by $R z(5,6)$

In the presence of their normal targets, $\mathrm{Rz}(5,6)$ do not innervate body wall structures of their own segments, even if that tissue remains uninnervated by any other $\mathrm{Rz}$ cell. Hence, $\mathrm{Rz}(5,6)$ do not compete with $\mathrm{Rz}(4,7)$ for this target. Following ablation of reproductive tissue, $\mathrm{Rz}(5,6)$ neurites do innervate body wall, yet even in these embryos, they grow more slowly than those of standard Rz cells. The serotonergic innervation of segments 5 and 6 following reproductive tissue ablation proceeds essentially at the normal rate, which is slower than that of adjacent segments, indicating that $\mathrm{Rz}(5,6)$ innervate the body wall at best only as rapidly as the secondary fields of Rz $(4,7)$ are es- tablished. This is unlikely to be due to nonspecific effects of damage: processes in the PP and DP nerves grow normally but are closer to the sites of operation than the slightly retarded processes in the A nerve. These results leave open several possibilities: that $\mathrm{Rz}(5,6)$ processes may follow those of $\mathrm{Rz}(4,7)$; that $\mathrm{Rz}(5,6)$ may compete with $\mathrm{Rz}(4,7)$ when forced to innervate body wall; or that $\mathrm{Rz}(5,6)$ may independently innervate body wall poorly. It should be possible to distinguish among these hypotheses by ablating both reproductive tissue and adjacent $\mathrm{Rz}$ cells in the same embryo.

When reproductive tissue was ablated, most $\mathrm{Rz}(5,6)$ developed similarly, but not identically to standard Rz cells. Taken together, these and previous results (Loer et al., 1987) suggest that there may be some differences between $\mathrm{Rz}(5,6)$ and standard Rz cells; these may be intrinsic or conferred by cells other than those of the target (e.g., by cells within the ganglion). For example, $\mathrm{Rz}(5,6)$ may have an intrinsic preference for repro- 

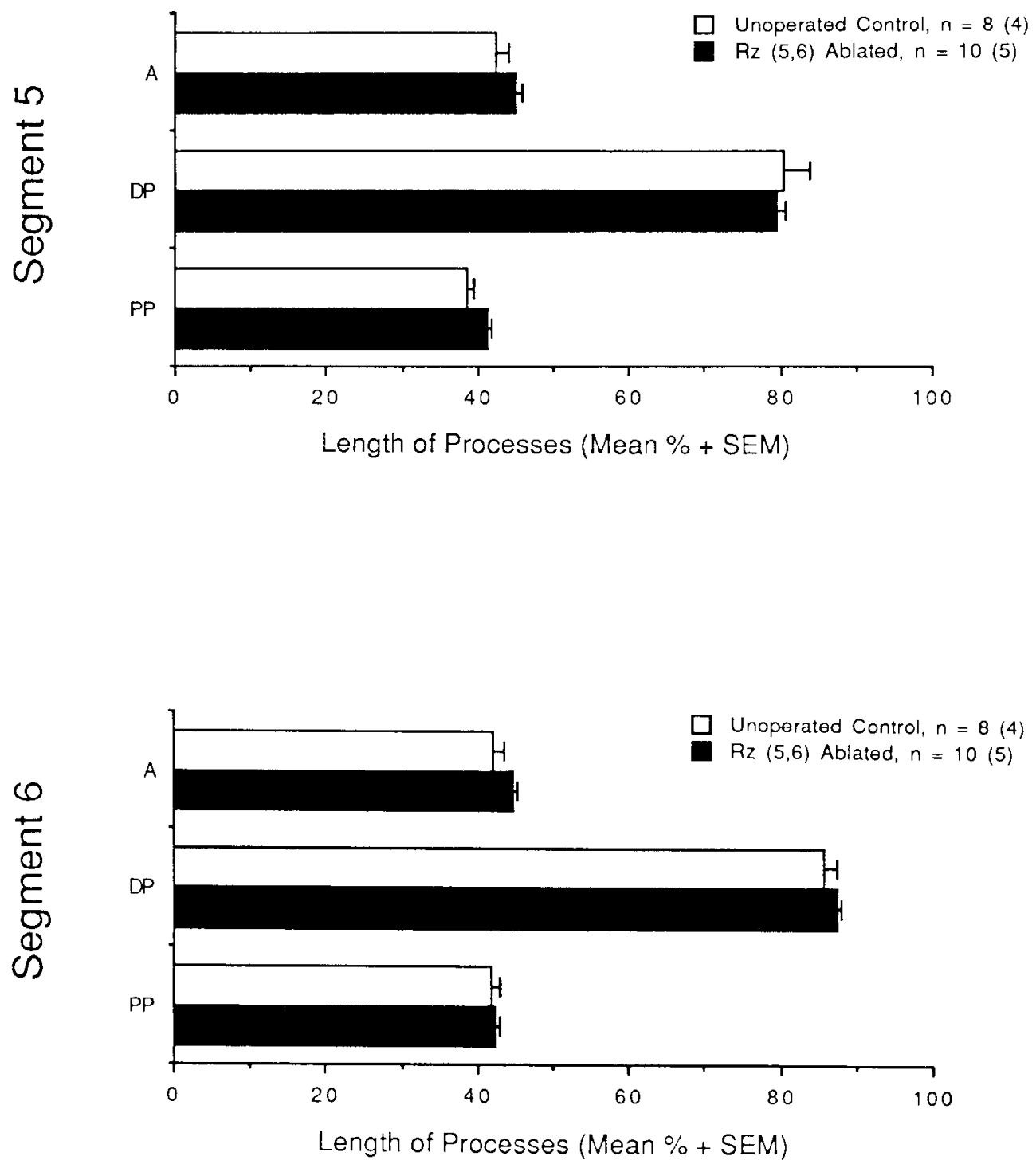

Figure 11. Extent of lateral growth of processes in the A, PP, and DP nerves of segments 5 and 6 in $\mathrm{Rz}(5,6)$-ablated and unoperated control embryos. The embryos were dissected $4 \mathrm{~d}$ after the manipulation. Mean (+SEM) length of process is expressed as a percentage of the distance from the ganglion to the edge of the germinal plate (see Materials and Methods). $n$ indicates the number of hemisegments measured; number in parentheses indicates the number of embryos. ductive tissue over body wall. This target choice would allow $\mathrm{Rz}(5,6)$ to interact with reproductive tissue, which could then cause them to differentiate as "reproductive" Rz cells. As with our previous results, however, it is possible that the timing of the reproductive tissue ablations or the presence of unseen target tissue remaining after ablation or interactions with nontarget cells causes the apparent limitations in the plasticity of $R z(5,6)$, rather than actual intrinsic differences between $\mathrm{Rz}(5,6)$ and standard $\mathrm{Rz}$ cells. Earlier ablations, before $\mathrm{Rz}(5,6)$ has any possibility of contact with reproductive tissue, or transplantation of $\mathrm{Rz}(5,6)$ to standard ganglia, might reveal more complete plasticity of these cells.

\section{Target choice by $R z(4,7)$}

The secondary fields of $\mathrm{Rz}(4,7)$ normally provide the serotonergic innervation of segments 5 and 6 . The results of ablations of $R z(4,7)$ alone suggested that tertiary fields of $R z(3,8)$ may innervate these segments as well. It is unclear whether most $\mathrm{Rz}$ cells normally possess tertiary fields, although those in G1 and the subesophageal ganglia often do (J. Jellies and C. Loer, unpublishcd observations). In $16 \mathrm{~d}$ embryos, $\mathrm{Rz}(4,7)$ filled with HRP often had axons in the interganglionic connectives between
G5 and G6 (Fig. 3), sometimes extending into the second adjacent ganglion and toward the peripheral nerves. Furthermore, the lateral connective tract in which $\mathrm{Rz}$ axons run has similar anti-5-HT staining between G5 and G6 as between other ganglia, even after $R z(5,6)$ have fully retracted their connective axons. At least $2 \mathrm{Rz}$ axons run in this tract between standard segmental ganglia; between G5 and G6, at least one $\mathrm{Rz}$ axon must be present to account for this staining. Therefore, it appears that $\mathrm{Rz}$ (4) and (7) may each normally innervate both segments 5 and 6 by way of secondary and tertiary fields.

Why do $\mathrm{Rz}(4,7)$ innervate body wall in segments 5 and 6 rather than reproductive tissue? One possibilty was that $\mathrm{Rz}(5,6)$ fill the available territory on the reproductive tissue before $\mathrm{Rz}$ $(4,7)$ branches arrive, leaving access only to the secondary target, body wall. Our results strongly indicate otherwise. Following the ablation of $\mathrm{Rz}(5,6)$, innervation of segments 5 and 6 by $\mathrm{Rz}$ $(4,7)$ is the same as in unoperated embryos; thus, $\mathrm{Rz}(4,7)$ and $\mathrm{Rz}(5,6)$ do not compete for reproductive tissue.

The results presented here demonstrate that $\mathrm{Rz}(4,7)$ and $\mathrm{Rz}$ $(5,6)$ do not normally compete for either of their 2 possible targets. These experiments do not, however, distinguish between 2 other possibilities for why $\mathrm{Rz}$ cells innervate different targets. 
First, target preferences of $\mathrm{Rz}(4,7)$ and $\mathrm{Rz}(5,6)$ may be intrinsically different. Alternatively, since processes of $\mathrm{Rz}(4,7)$ reach segments 5 and 6 considerably later than do those of $R z(5,6)$, the timing of their contact with reproductive tissue may be the determining factor-the target tissue may no longer be competent to attract $\mathrm{Rz}$ cell processes, or $\mathrm{Rz}(4,7)$ may no longer be competent to respond to the target. These issues are considered in the following paper (Loer and Kristan, 1989).

\section{Neuronal competition during leech embryogenesis}

Clear examples of competition between neurons have been found in the developing leech embryo both for peripheral projections and for survival. Some neurons (AE, AP, and HA) in the leech normally extend axons interganglionically to adjacent segments during embryogenesis but later retract them from segments that contain their segmental homologs. In the absence of their segmental homologs, whether occurring naturally or produced by experimental manipulation, the neurons retain their interganglionic axons and extend to the periphery (Wallace, 1984; Gao and Macagno, 1987a-c). HA neurons also innervate exclusive peripheral territories; AE (annulus erector) motorneurons, on the other hand, have considerable functional overlap with their segmental homologs (Stuart, 1970), although it is unknown whether they overlap at a fine anatomical level. Competition for peripheral territory, however, is seen even in the adult: Elimination of a single AE motorneuron eventually leads adjacent AE motorneurons to expand into the vacant region (Bowling et al., 1978). $\mathrm{Rz}$ cells and cutaneous sensory neurons (T, P, N) normally overlap freely with their segmental homologs, both in their projections to adjacent ganglia and in their peripheral territories (Yau, 1976; Jellies et al., 1987). It is unclear why the 2 groups of neurons develop by such different rules.

Other neurons in the leech embryo seem to compete for survival. The posteromedial serotonin (PMS) cells originate as a bilateral pair located roughly on the midline of each segmental ganglion. In most segments, one of the cells later dies (Macagno and Stewart, 1987; Stuart et al., 1987). Death of one PMS neuron is apparently due to competition because when the precursors of the PMS neurons are eliminated on one side, all PMS neurons from the intact side survive (Stuart et al., 1987). It is likely that the PMS neurons interact with their bilateral homologs within the ganglion and with segmental homologs in adjacent ganglia by way of interganglionic axons; it is possible that they compete for trophic substances, perhaps derived from specific targets. It is clear that these neurons, too, develop by rules different from those of $\mathrm{Rz}$ cells.

\section{Target choice in other preparations}

When a normal target is present, appropriatc target sclection by neurons in some preparations can occur despite considerable perturbation. Limited rotations of spinal cord or particular reversals of hindlimbs in the chick do not alter the innervation of muscles by their appropriate motor neuron pools (LanceJones and Landmesser, 1980; Ferguson, 1983). Retinal ganglion cells from eyes transplanted to various sites on the head still grow to the tectum albeit along abnormal routes (Harris, 1986). Target choice in these examples seems strongly determined; all that is necessary is an adequate pathway to the appropriate location. In the absence of the correct target, neurons exhibit a variety of responses. Neurons in the chick that normally innervate local epaxial muscles seek homologous targets in a nearby segment (Tosney, 1987), whereas ventral limb motor neurons will innervate transplanted dorsal muscle that is located ventrally (Lance-Jones, 1986). Insect motor neurons will also innervate foreign muscles in the absence of their normal targets (Whitington, 1985). Such examples suggest that a hierarchy of intrinsic information and successive external cues are probably necessary to match a neuron to its correct target.

\section{References}

Bowling, D., J. Nicholls, and I. Parnas (1978) Destruction of a single cell in the central nervous system of the leech as a means of analysing its connexions and functional role. J. Physiol. (Lond.) 282: 169-180.

Caudy, M., and D. Bentley (1986) Pioneer growth cone steering along a series of neuronal and non-neuronal cues of different affinities. $J$. Neurosci. 6: 1781-1795.

Doupe, A. J., S. C. Landis, and P. H. Patterson (1985) Environmental influences in the development of neural crest derivatives: Glucocorticoids, growth factors, and chromaffin cell plasticity. J. Neurosci. 5: 2119-2142.

Ferguson, B. A. (1983) Development of motor innervation of the chick following dorso-ventral limb bud rotations. J. Neurosci. 3: 17601772.

Fernandez, J., and G. Stent (1982) Embryonic development of the hirudinid leech Hirudo medicinalis: Structure, development and segmentation of the germinal plate. J. Embryol. Exp. Morphol. 72: 7196.

Fujii, J. T., and D. W. Berg (1987) Formation of calyx-like contacts preferentially on appropriate target neurons in culture. Dev. Biol. 123: 346-353.

Gao, W.-Q., and E. R. Macagno (1987a) Extension and retraction of axonal projections by some developing neurons in the leech depends upon the existence of neighboring homologues. I. The HA cells. J. Neurobiol. 18: 43-59.

Gao, W.-Q., and E. R. Macagno (1987b) Extension and retraction of axonal projections by some developing neurons in the leech depends upon the existence of neighboring homologues. II. The AP and AE neurons. J. Neurobiol. 18: 295-313.

Gao, W.-Q., and E. R. Macagno (1987c) Selective neurite retraction by some leech neurons can be prevented by cutting ganglionic nerve roots early in development. Soc. Neurosci. Abstr. 13: 256.

Glover, J. C., and A. Mason (1986) Morphogenesis of an identified leech neuron: Segmental specification of axonal outgrowth. Dev. Biol. 115: 256-260.

Harris, W. A. (1986) Homing behavior of axons in the embryonic vertebrate brain. Nature 320:266-269.

Jellies, J., and W. B. Kristan, Jr. (1988) An identified cell is required for the formation of a major nerve during embryogenesis in the leech. J. Neurobiol. 19: 153-165.

Jellies, J., C. M. Loer, and W. B. Kristan, Jr. (1987) Morphological changes in leech Retzius neurons after target contact during embryogenesis. J. Neurosci. 7: 2618-2629.

Kristan, W. B., Jr., G. S. Stent, and C. A. Ort (1974) Neuronal control of swimming in the medicinal leech. I. Dynamics of the swimming rhythm. J. Comp. Physiol. 94: 97-119.

Lamb, A. H. (1981) Target dependency of developing motoneurons in Xenopus laevis. J. Comp. Neurol. 203: 157-171.

Lance-Jones, C. C. (1986) Motoneuron projection patterns in chick embryonic limbs with a double complement of dorsal thigh musculature. Dev. Biol. 116: 387-408.

Lance-Jones, C., and L. Landmesser (1980) Motoneurone projection patterns in the chick hind limb following early partial reversals of the spinal cord. J. Physiol. (Lond.) 302: 581-602.

Landis, S. C., and D. Keefe (1983) Evidence for neurotransmitter plasticity in vivo: Developmental changes in properties of cholinergic sympathetic neurons. Dev. Biol. 98: 349-372.

Leake, L. D., S. G. Griffith, and G. Burnstock (1985) 5-Hydroxytryptamine-like immunoreactivity in the peripheral and central nervous systems of leech Hirudo medicinalis. Cell Tissue Res. 239: 123-130.

Loer, C. M. (1988) Target specification of morphology and synaptic connectivity of identified neurons during embryogenesis of the leech. Doctoral dissertation, University of California, San Diego.

Loer, C. M., and W. B. Kristan, Jr. (1989) Peripheral target choice by homologous ncurons during embryogenesis of the medicinal leech. II. Innervation of ectopic reproductive tissue by nonreproductive Retzius cells. J. Neurosci. 9: 528-538. 
Loer, C. M., J. Jellies, and W. B. Kristan, Jr. (1987) Segment-specific morphogenesis of leech Retzius neurons requires particular peripheral targets. J. Neurosci. 7: 2630-2638.

Macagno, E. R., and R. R. Stewart (1987) Cell death during gangliogenesis in the leech: Competition leading to death of PMS neurons has both random and nonrandom components. J. Neurosci. 7: 19111918.

Miller, J. P., and A. I. Selverston (1979) Rapid killing of single neurons by irradiation of intracellularly injected dye. Science $206: 702-704$.

Myers, P. Z., J. S. Eisen, and M. Westerfield (1986) Development and axonal outgrowth of identified motoneurons in the zebrafish. J. Neurosci. 6: 2278-2289.

Ort, C. A., W. B. Kristan, Jr., and G. Stent (1974) Neuronal control of swimming in the medicinal leech. II. Identification and connections of motor neurons. J. Comp. Physiol. 94: 121-154.

Pilar, G. L., L. Landmesser, and L. Burstein (1980) Competition for survival among ciliary ganglion cells. J. Neurophysiol. 43: 233-254.

Raper, J. A., M. Bastiani, and C. S. Goodman (1983) Pathfinding by neuronal growth cones in grasshopper embryos. II. Selective fasciculation onto specific axonal pathways. J. Neurosci. 3: 31-41.

Schotzinger, K. J., and S. C. Landis (1987) Target regulation of neurotransmitter properties in rat sympathetic neurons: Evidence from sweat gland transplantation. Soc. Neurosci. Abstr. 13: 1616.

Smith, C. L., and E. Frank (1987) Peripheral specification of sensory neurons transplanted to novel locations along the neuraxis. J. Neurosci. 7: $1537-1549$.
Sokal, R. R., and F. J. Rohlf (1981) Biometry, 2nd ed., W. H. Freeman, New York.

Stuart, A. E. (1970) Physiological and morphological properties of motoneurones in the central nervous system of the leech. J. Physiol. (Lond.) 209: 627-646.

Stuart, D. K., S. S. Blair, and D. A. Weisblat (1987) Cell lineage, cell death, and the developmental origin of identified serotonin- and dopamine-containing neurons in the leech. J. Neurosci. 7: 1107-1122.

Tosney, K. W. (1987) Proximal tissues and patterned neurite outgrowth at the lumbosacral level of the chick embryo: Deletion of the dermamyotome. Dev. Biol. 122: 540-558.

Tosney, K. W., and L. T. Landmesser (1985) Specificity of early motoneuron growth cone outgrowth in the chick embryo. J. Neurosci. 5: 2336-2344.

Voyvodic, J. T. (1987) Dendritic geometry of sympathetic ganglion cells is regulated by postganglionic target size. Soc. Neurosci. Abstr. 13: 574 .

Wallace, B. G. (1984) Selective loss of neurites during differentiation of cells in the leech central nervous system. J. Comp. Neurol. 228: $149-153$.

Whitington, P. M. (1985) Functional connections with foreign muscles made by a target-deprived insect motorneuron. Dev. Biol. 107: $537-$ 540.

Yau, K.-W. (1976) Receptive fields, geometry and conduction block of sensory neurones in the central nervous system of the leech. J. Physiol. (Lond.) 263: 513-538. 